\title{
Comparison of interval duration between single course antenatal corticosteroid administration and delivery on neonatal outcomes
}

\author{
Doğum öncesi tek kür kortikosteroid uygulaması ile doğum arasındaki sürenin yeni \\ doğan akibeti üzerine etkisinin karşılaştırılması
}

\author{
Leila Sekhavat ${ }^{1}$, Raziah Dehghani Firouzabadi ${ }^{2}$, Sedighah Akhavan Karbasi ${ }^{3}$ \\ 'Department of Obstetrics and Gynecology, Shahid Sadughi University of Medical Sciences, Yazd, Iran \\ ${ }^{2}$ Department of Infertility, Shahid Sadughi University of Medical Sciences, Yazd, Iran \\ ${ }^{3}$ Department of Pediatrics, Shahid Sadughi University of Medical Sciences, Yazd, Iran
}

\section{Abstract}

Objective: This study was performed to determine the effect of antenatal corticosteroid the interval between administration and delivery affect on neonatal outcomes.

Material and Methods: An observational study was performed on all deliveries between 28-34 weeks gestation where delivery occurred vaginally after completing a single course of antenatal corticosteroid (dexamethasone). Women were divided into 3 groups on the basis of the interval from first corticosteroid dose to delivery $(<2$ days, 2-7 and $>7$ days). The primary outcome was the need for neonatal resuscitation and the secondary outcome was respiratory distress syndrome (RDS), which was described as "need for ventilation with positive pressure $\mathrm{O} 2$ during the first $24 \mathrm{hrs}$ of life". P value $<0.05$ was significant.

Results: Of 104 neonates whose mothers received a full course of antenatal corticosteroid, 29 delivered $<2$ days, 41 delivered 2-7 days, and 34 delivered more than 7 days after the initial dose. Overall, those delivering within 2 days after the first injection of corticosteroid had more need for resuscitation and ventilation than those infants delivering between 2-7 days and after 7 days. Infants delivering between 2-7 days had a lower incidence of need for resuscitation and receiving respiratory support for more than 24 hours.

Conclusion: We found that the interval between corticosteroid administration and delivery influences the incidence of need for resuscitation and ventilation. Infants delivering less than 2 days of corticosteroid exposure have a higher frequency of need for resuscitation and ventilation than delivering between 2-7 days and after 7 days.

(J Turkish-German Gynecol Assoc 2011; 12: 86-9)

Key words: Corticosteroids, ventilation, need to resuscitation, preterm delivery

Received: 30 December, 2010

Accepted: 12 April, 2011

\section{Özet}

Amaç: Bu çalışma doğum öncesi kortikosteroid uygulaması ve doğum arasındaki intervalin yeni doğan akibeti üzerine etkisini belirlemek için gerçekleştirildi.

Gereç ve Yöntemler: 28-34 gebelik haftaları arasında ve doğum öncesi tek bir kortikosteroid (deksametazon) kürünün tamamlanmasından sonra görülen vajinal doğumlarda gözlemsel bir çalışma gerçekleştirildi. Kadınlar ilk kortikosteroid dozundan doğuma kadar geçen süreye dayalı olarak 3 gruba ayrıldı ( $<2$ gün, $2-7$ ve $>7$ gün). Birincil sonuç yenidoğan resüsitasyonuna gerek duyulması, ikincil sonuç respiratuar distres sendromu (RDS) idi; RDS "yaşamın ilk 24 saatinde pozitif basınçlı $\mathrm{O} 2$ ile ventilasyona gerek duyulması" olarak tanımlandı. $P$ değeri $<0.05$ anlamlı idi.

Bulgular: Anneleri doğum öncesi tam kür kortikosteroid alan 104 yenidoğanın, başlangıç dozundan sonra 29'u <2 günde, 41'i 2- 7 günde ve 34 'ü $>7$ günde doğdu. Toplamda, kortikosteroidin ilk enjeksiyonundan sonra 2 gün içinde doğanlar; 2-7 gün arasında ve 7 günden sonra doğanlardan daha fazla resüsitasyona ve ventilasyona gerek duydu. 2-7 gün arasında doğan bebeklerin resüsitasyona ve 24 saatten daha uzun süre solunum desteğine gereksinim insidansı daha düşüktü.

Sonuç: Kortikosteroid uygulaması ve doğum arasındaki intervalin resüsitasyon ve ventilasyon gereksinimi insidansını etkilediğini bulduk. Kortikosteroid uygulanmasından sonra 2 günden daha kısa sürede doğan bebekler 2-7 gün arasında ve 7 günden sonra doğanlara göre daha yüksek sıklıkla resüsitasyona ve ventilasyona gerek duymaktadır.

(J Turkish-German Gynecol Assoc 2011; 12: 86-9)

Anahtar kelimeler: Kortikosteroidler, ventilasyon, resüsitasyon gereksinimi, preterm doğum

Geliş Tarihi: 30 Aralık 2010

Kabul Tarihi: 12 Nisan 2011

\section{Introduction}

Preterm labor and preterm delivery are critical factors affecting neonatal morbidity and mortality (1). The most common complication of premature birth is respiratory distress syndrome (RDS), which is caused by insufficient surfactant production in the immature fetal lung (2). In 1972, Liggins reported that use of corticosteroids in the antenatal period improves the outcome of infants who deliver between 28 and 34 weeks of gestation (3).

During most of its gestational life, the fetus is exposed to very low levels of corticosteroids. A surge of corticosteroids in late pregnancy stimulates fetal lung surfactant production which is necessary for lung maturation. In preterm labor 
the neonate does not experience the late gestational steroid surge. These premature infants experience respiratory distress syndrome (RDS) and require mechanical lung ventilation (4). Synthetic corticosteroids exhibit transplacental passage when administered to pregnant women because of the low affinity for maternal corticosteroid binding globulin (CBG) and poor breakdown by placental steroid metabolizing enzymes (5). This treatment consists of corticosteroid administration for 48 hours, which is thought to stimulate innate surfactant production before delivery. Studies demonstrated improved respiratory outcomes among infants delivering within 7 days of corticosteroid therapy $(5,6)$.

Based on the original data of Liggins and Howie, where a positive effect of the corticosteroids was described up to 7 days, 2 R.N. Howie and G.C. Liggins, The New Zealand study of antepartum glucocorticoid treatment. In: P.M. Farrell, Editor, Lung development: biological and clinical perspectives Vol 2, Academic Press, New York (1982), pp. 255-265. the practice evolved to administer this treatment to undelivered at-risk patients on a weekly basis until delivery or maturity was reached (2). Whereas the positive effect of a single course of antenatal corticosteroids for fetal lung maturation is proven, the usefulness of repetitive administration of corticosteroids is still under investigation and unclear (7). Recent studies reported that the neonatal benefits do not diminish when delivery is beyond 7 days from the initial antenatal corticosteroids dose $(2,8)$. Some studies documented no beneficial or even adverse effects of multiple antenatal corticosteroids courses (9). In the controversy regarding some of these, some studies reported that a time interval of $>14$ days between the administration of antenatal corticosteroids and delivery is associated with an increased need for ventilatory support and surfactant use in neonates who deliver preterm $(10,11)$.

The objective of this study was to evaluate the effect of the time interval between the last corticosteroid treatment and delivery, and whether a prolonged interval ( $>7$ days) between antenatal corticosteroid therapy and delivery is associated with increased neonatal respiratory morbidity.

\section{Materials and Methods}

An observational study was designed and conducted on 104 preterm women who were between 28-34 weeks gestation and undergoing vaginal delivery after completing a single course of antenatal corticosteroid (Dexamethasone). The study was carried out in the obstetrics department of Shahid Sedughi hospital (University referral center) between 2006-2008. The adopted protocol was approved by the hospital research and ethics committee. The sample size estimation was based on studies with the hypothesis of need for respiratory support at gestational ages 26 to 34 weeks and using a Mann-Whitney test with a 0.05 two-sided significance level (n Query Advisor, Version 5.0). All women were interviewed individually by the researcher. Written informed consent was obtained from all the patients. The questionnaires were filled out for each patient at the beginning of the study and detailed information was collected on all deliveries by an obstetrics first year resident. Gestational age was based on the last menstrual period and/or ultrasonographic measurement of crown-rump length in early pregnancy and after 12 weeks gestation by ultrasonic measurement of fetal biparietal diameter and femur length. Individuals who reviewed the maternal charts were blinded to neonatal outcome data. Neonatal data were collected prospectively for infants admitted to the neonatal intensive care unit.

Only neonates of mothers who received a complete course of antenatal corticosteroids were included. A single course was defined as Dexamethasone in a dosage of $6 \mathrm{mg}$ given intramuscularly every 12 hours for two days (12). Patients were grouped on the basis of the time interval between the administration of the first corticosteroid dose and delivery, $<2$ days, 2-7 days and $>7$ days. Multiple gestations and neonates with congenital anomalies were excluded. Also the women with preeclampsia, severe maternal disease, receiving tocolytic agent, women with a diagnosis of preterm premature rupture of membranes, chorioamnionitis and cases in which delivery occurred after 34 weeks gestation were excluded. Neonates delivering within 7 days and after 7 days of initiation of corticosteroid treatment were compared with those delivering $<2$ days from treatment initiation in regard to the need for resuscitation and respiratory morbidities (including need for respiratory support by mechanical ventilation or continuous positive airway pressure for $>24$ hours).

Data was analyzed with SPSS 11.5 software using the Student $\mathrm{t}$ test, Mann Whitney $\mathrm{U}$ test and $\chi^{2}$ testing. $\mathrm{P}$ value $<0.05$ was considered statistically significant.

\section{Results}

One hundred and four women were identified who delivered between 2006 and 2008 at 28 - 34 weeks gestation and had received a single course of antenatal corticosteroid therapy for the purpose of advancing pulmonary maturity. Of 104 neonates whose mothers received antenatal corticosteroid, 29 delivered $<2$ days, 41 delivered 2-7 days, and 34 delivered more than 7 days after the initial dose. The groups were similar in gestational age at delivery, maternal age, gender, and birth weight (Table 1). The groups differed only in the interval from treatment to delivery, as expected by group assignment. Neonates delivering between 2-7 days of treatment had lower rates of resuscitation and ventilation. Infants delivering in under 2 days had more resuscitation and ventilation than those who delivered 2-7 days of treatment $(20(68.7 \%)$ vs $18(43.9 \%)$ and $25(83.1 \%)$ vs 21 (51.2\%), $\mathrm{p}=0.01$ and $\mathrm{p}=0.001$ respectively) (Table 2). Table 3 shows that both resuscitation and ventilation were significantly less in deliveries after 7 days compared with infants delivering $<2$ days of treatment (20 (68.7\%) vs $17(50 \%)$ and $25(83.1 \%)$ vs $25(73.5 \%) \mathrm{p}<0.05)$, but the need to resuscitate was similar. Of 104 neonates whose mothers received a full course of antenatal corticosteroid, 35 (33.7\%) were $<32$ weeks of gestation. Common odds ratios are presented for analyses that were stratified by gestational age. Of these, 10 neonates delivered $<2$ days, 17 neonates delivered 2-7 days and 8 neonates delivered after 7 days of antenatal corticosteroid exposure. Table 4 shows 
that differences between groups in respiratory outcomes were most evident for neonates at $<32$ weeks of gestational age. APGAR score in neonates delivering between 2-7 days of treatment was higher than the others, but this was not significant.

Comparison of neonatal respiratory outcomes of $<32$ weeks of gestation who delivered after 7 days and 2-7 days after antenatal corticosteroid administration is given in Table 5. Delivering after 7 days of corticosteroid administration have significantly better outcome.

\section{Discussion}

The most common complication of premature birth is respiratory distress syndrome (RDS), which is caused by insufficient surfactant production in the immature fetal lung (2). Studies showed that antenatal corticosteroid therapy for fetal maturation is effective and reduces perinatal mortality and pulmonary and cerebral morbidity in preterm infants $(7,13)$. The most effective timing for administration has not been established. Clinical evidence suggests that antenatal steroids are most effective in deliveries between 24 hours and 7 days after treatment, but that the benefits of treatment may begin to decrease after 7 days (2). It is unclear whether the beneficial effects of antenatal corticosteroid therapy diminish with time. Therefore, many clinicians prefer to repetitively administer corticosteroids

Table 1. Baseline demographic characteristics between groups

\begin{tabular}{|c|c|c|c|c|}
\hline Characteristics & $\begin{array}{l}\text { Delivery } \\
\leq 2 \text { days } \\
(n=29)\end{array}$ & $\begin{array}{c}\text { Delivery } \\
\text { within } 7 \text { days } \\
(n=41)\end{array}$ & $\begin{array}{l}\text { Delivery } \\
>7 \text { days } \\
(n=34)\end{array}$ & $\begin{array}{c}P \\
\text { value }\end{array}$ \\
\hline $\begin{array}{l}\text { Maternal age (year) } \\
(\text { Mean } \pm \text { SD) }\end{array}$ & $28.4 \pm 6.1$ & $27.8 \pm 6.4$ & $28.0 \pm 6.7$ & 0.4 \\
\hline \multicolumn{5}{|l|}{ Parity (N (\%)) } \\
\hline Nullipara & $12(41.4)$ & $22(53.7)$ & $16(47.1)$ & 0.2 \\
\hline Multipara & $17(58.6)$ & $19(46.3)$ & $18(52.9)$ & \\
\hline $\begin{array}{l}\text { Gestational age } \\
\text { at initiation of } \\
\text { treatment (week) } \\
(\text { Mean } \pm \text { SD) }\end{array}$ & $30.1 \pm 2.5$ & $30.8 \pm 2.8$ & $31.5 \pm 2.2$ & 0.4 \\
\hline $\begin{array}{l}\text { Gestational age } \\
\text { at delivery (week) } \\
(\text { Mean } \pm \text { SD) }\end{array}$ & $31.7 \pm 2.3$ & $31.5 \pm 2.8$ & $31.7 \pm 2.0$ & 0.3 \\
\hline \multicolumn{5}{|l|}{ Mode of delivery } \\
\hline Vaginal & $16(55.2)$ & $21(51.2)$ & $15(44.1)$ & \multirow[t]{2}{*}{0.1} \\
\hline Cesarean section & $13(44.8)$ & $20(48.8)$ & $19(55.9)$ & \\
\hline \multicolumn{5}{|l|}{$\begin{array}{l}\text { Neonatal gender } \\
(\mathrm{N}(\%))\end{array}$} \\
\hline Male & $18(62.1)$ & $23(56.1)$ & $14(41.2)$ & \multirow[t]{2}{*}{0.1} \\
\hline Female & $11(37.9)$ & $18(43.9)$ & $20(58.8)$ & \\
\hline $\begin{array}{l}5 \text { minutes APGAR } \\
\text { score (Median) }\end{array}$ & 5 & 8 & 6 & 0.02 \\
\hline $\begin{array}{l}\text { Birth weight (g) } \\
(\text { Mean } \pm \text { SD) }\end{array}$ & $1451 \pm 385$ & $1424 \pm 349$ & $1460 \pm 361$ & 0.3 \\
\hline
\end{tabular}

Table 2. Comparison of respiratory outcomes among neonates who delivered $<2$ days and 2-7 days after antenatal corticosteroid administration

\begin{tabular}{|l|c|c|c|}
\hline Variable & $\begin{array}{c}\text { Corticosteroid } \\
\text { exposure } \\
\text { <2 days } \\
(\mathbf{n = 2 9 )}\end{array}$ & $\begin{array}{c}\text { Corticosteroid } \\
\text { exposure } \\
\mathbf{2 - 7} \text { Days } \\
(\mathbf{n = 4 1 )}\end{array}$ & $\begin{array}{c}\mathbf{P} \\
\text { value }\end{array}$ \\
\hline $\begin{array}{l}\text { Need to resuscitation } \\
(\mathrm{N}(\%))\end{array}$ & $20(68.7)$ & $18(43.9)$ & 0.001 \\
\hline $\begin{array}{l}\text { Ventilation for }>24 \mathrm{~h} \\
(\mathrm{~N}(\%))\end{array}$ & $25(83.1)$ & $21(51.2)$ & 0.001 \\
\hline $\begin{array}{l}\text { Total days of NICU } \\
(\text { Mean } \pm \text { SD) }\end{array}$ & $9 \pm 3.21$ & $12 \pm 4.885$ & 0.001 \\
\hline
\end{tabular}

Table 3. Comparison of respiratory outcomes among neonates who delivered 2 - 7 days and after 7 days after antenatal corticosteroid administration

\begin{tabular}{|l|c|c|c|}
\hline Variable & $\begin{array}{c}\text { Corticosteroid } \\
\text { exposure } \\
\text { <2 days } \\
(\mathbf{n = 2 9 )}\end{array}$ & $\begin{array}{c}\text { Corticosteroid } \\
\text { exposure } \\
\mathbf{>} \text { 7 days } \\
\mathbf{( n = 3 4 )}\end{array}$ & $\begin{array}{c}\mathbf{P} \\
\text { value }\end{array}$ \\
\hline $\begin{array}{l}\text { Need for resuscitation } \\
(\mathrm{N}(\%))\end{array}$ & $20(68.7)$ & $17(50)$ & 0.01 \\
\hline $\begin{array}{l}\text { Ventilation for }>24 \mathrm{~h} \\
(\mathrm{~N}(\%))\end{array}$ & $25(83.1)$ & $25(73.5)$ & 0.001 \\
\hline
\end{tabular}

Table 4. Comparison of neonatal respiratory outcomes of $<32$ weeks of gestation who delivered $<2$ days and 2-7 days after antenatal corticosteroid administration

\begin{tabular}{|l|c|c|c|c|}
\hline Variable & $\begin{array}{c}\text { Corticosteroid } \\
\text { exposure } \\
\text { <2 days } \\
(\mathbf{n = 1 0 )}\end{array}$ & $\begin{array}{c}\text { Corticosteroid } \\
\text { exposure } \\
\mathbf{2 - 7} \text { days } \\
\mathbf{( n = 1 7 )}\end{array}$ & $\begin{array}{c}\text { Odds ratio } \\
\mathbf{( 9 5 \% ~ C I )}\end{array}$ & $\begin{array}{c}\mathbf{P} \\
\text { value }\end{array}$ \\
\hline $\begin{array}{l}\text { Need for } \\
\text { resuscitation } \\
(\mathrm{N}(\%))\end{array}$ & $7(70)$ & $7(41.2)$ & $\begin{array}{c}2.1 \\
(1.9-3.7)\end{array}$ & 0.001 \\
\hline $\begin{array}{l}\text { Ventilation } \\
\text { for }>24 \mathrm{~h} \\
(\mathrm{~N}(\%))\end{array}$ & $9(90)$ & $10(58.8)$ & $\begin{array}{c}2.8 \\
(1.9-3.9)\end{array}$ & 0.001 \\
\hline
\end{tabular}

Table 5. Comparison of neonatal respiratory outcomes of $<32$ weeks of gestation who delivered after 7 days and 2-7 days after antenatal corticosteroid administration

\begin{tabular}{|l|c|c|c|c|}
\hline Variable & $\begin{array}{c}\text { Corticosteroid } \\
\text { exposure } \\
\mathbf{2} \text { days } \\
(\mathbf{n = 1 0 )}\end{array}$ & $\begin{array}{c}\text { Corticosteroid } \\
\text { exposure } \\
\mathbf{7} \text { days } \\
\mathbf{( n = 8 )}\end{array}$ & $\begin{array}{c}\text { Odds ratio } \\
\mathbf{( 9 5 \% ~ C I )}\end{array}$ & $\begin{array}{c}\mathbf{P} \\
\text { value }\end{array}$ \\
\hline $\begin{array}{l}\text { Need for } \\
\text { resuscitation } \\
(\mathrm{N}(\%))\end{array}$ & $7(70)$ & $4(50)$ & $\begin{array}{c}2.3 \\
(1.8-3.7)\end{array}$ & 0.001 \\
\hline $\begin{array}{l}\text { Ventilation } \\
\text { for }>24 \mathrm{~h} \\
(\mathrm{~N}(\%))\end{array}$ & $9(90)$ & $6(75)$ & $\begin{array}{c}2.1 \\
(1.1-3.4)\end{array}$ & 0.001 \\
\hline
\end{tabular}


to pregnant women who have not been delivered within 7 days of initial treatment and are still at high risk for preterm delivery. Some studies reported no beneficial or even adverse effects after multiple courses of antenatal corticosteroids $(9,14)$.

Our studies evaluated the effect of interval between a single dose of antenatal corticosteroid and delivery on neonatal outcome (need for resuscitation and ventilation for more than 24 hours), and showed that, when delivery occurred between 2 -7 after a single dose of corticosteroid, treatment can be more effective than $<2$ and $>7$ days. In this study, when delivery occurred in less than 2 days after the beginning of treatment, the need for resuscitation and ventilation were increased. Although in vitro experiments with human fetal lung explants have shown that the biochemical effects of steroid treatment also begins to decrease after 7 days (15), in our study only an increased need for ventilation for more than 24 hours was seen in those neonates delivering more than 7 days from treatment, but immediate resuscitation after birth was not similar to those delivering between 2-7 days.

The results provide more evidence for other studies. Peaceman et al, reported similar results in 2005 (2). However, they used both dexamethasone or betamethasone in their study and these drugs can effect with different intervals. Waters in 2008 also reported similar results (11). In contrast, Ring et al reported an increased risk for ventilatory support and surfactant use in neonates who delivered after 14 days following the administration of antenatal corticosteroids (10). This may be prolonged more than 2 weeks between administration and deliveries in this study. Another study performed by Ay in Turkey, showed there was no statistically significant difference between groups of single and two courses of antenatal steroid therapy regarding the incidence of RDS and mechanical ventilator treatment (16).

We used a single course of corticosteroid treatment in our study because of controversy in other studies (in multiple or single course of corticosteroid treatment and their results). Banks et al reported that multiple courses of antenatal corticosteroids did not improve neonatal outcome, especially no reduction of the RDS was found. The outcome of infants delivered 1-6 days or 7-13 days after receiving antenatal corticosteroids was similar (14); and conversely, Throp et al could show that prolonged antenatal betamethasone therapy improved neonatal outcome and is not associated with higher risks of maternal adverse effects (18). This study compared 28-34 week gestational age infants. Although Ring et al reported an increased need for ventilatory support and surfactant use in neonates who deliver at $>28$ weeks of gestation in their study $(\mathrm{H})$, our results showed that there were no difference in analyses <32 week of gestation and 32-34 weeks.

\section{Conclusion}

We found that theinterval between corticosteroid administration and delivery influences the incidence of need for resuscitation and ventilation. Infants delivering less than 2 days after corticosteroid exposure have a higher frequency of need for resuscitation and ventilation than those delivering between 2-7 days and after 7 days.

\section{Acknowledgments}

We thank the personnel of the Obstetrics and NICU Department for helping in data collection

\section{Conflict of interest}

No conflict of interest was declared by the authors.

\section{References}

1. Lee SS, Kwon HS, Choi HM. Evaluation of Preterm Delivery between 32-33 Weeks of Gestation. J Korean Med Sci 2008; 23: 964-8. [CrossRef]

2. Peaceman AM, Bajaj K, Kumar P, Grobman WA. The interval between a single course of antenatal steroids and delivery and its association with neonatal outcomes. Am J Obstet Gynecol 2005; 193: 1165-9. [CrossRef]

3. Liggins GC, Howie RN. A controlled trial of antepartum glucocorticoid treatment for prevention of the respiratory distress syndrome in premature infants, Pediatrics 1972; 50: 515-25.

4. Samtani MN, Pyszczynski NA, Dubois DC, Almon RR, Jusko WJ. Modeling glucocorticoid-mediated fetal lung maturation: I. Temporal patterns of corticosteroids in rat pregnancy. $\mathrm{J}$ Pharmacol Exp Ther 2006; 317: 117-26.

5. Mulder EJ, de Heus R, Visser GH. Antenatal corticosteroid therapy: short-term effects on fetal behaviour and haemodynamics. Semin Fetal Neonatal Med 2008; Dec 5.

6. Vermillion ST, Soper DE, Newman RB. Is betamethasone effective longer than 7 days after treatment? Obstet Gynecol 2001; 97: 491-3. [CrossRef]

7. Smrcek JM, Schwartau N, Kohl M, Berg C, Geipel A, Krapp M et al. Antenatal corticosteroid therapy in premature infants. Arch Gynecol Obstet 2005; 271: 26-32. [CrossRef]

8. Sehdev HM, Abbasi S, Robertson P, Fisher L, Marchiano DA, Gerdes JS et al. The effects of the time interval from antenatal corticosteroid exposure to delivery on neonatal outcome of very low birth weight infants. Am J Obstet Gynecol 2004; 191: 1409-13. [CrossRef]

9. Kay HH, Bird IM, Coe CL, Dudley D. Antenatal steroid treatment and adverse fetal effects: what is the evidence? J Soc Gynecol Investig 2000; 7: 269-78. [CrossRef]

10. Ring AM, Garland JS, Stafeil BR, Carr MH, Peckman GS, Pircon RA. The effect of a prolonged time interval between antenatal corticosteroid administration and delivery on outcomes in preterm neonates: a cohort study. Am J Obstet Gynecol 2007; 196: 457. [CrossRef]

11. Waters TP, Mercer B. Impact of timing of antenatal corticosteroid exposure on neonatal outcomes. J Matern Fetal Neonatal Med 2009; 16: 311-4. [CrossRef]

12. Guinn DA, Atkinson WA, Sullivan L, Lee MJ, MacGregor S, Parilla BV, et al. Single vs Weekly Courses of Antenatal Corticosteroids for Women at Risk of Preterm Deliveryt. JAMA 2001; 286: 1628-30.

13. Alan JH, Roger SF. Choice and dose of corticosteroid for antenatal treatments. American Journal of Obstetrics and Gynecology 2004; 190: 878-81.

14. Banks B, Cnaan A, Morgan A, Parer J, Merrill J, Ballard P, et al. Multiple courses of antenatal corticosteroids and outcome of premature neonates. Am J Obstet Gynecol 1999; 181: 709-17. [CrossRef]

15. NIH Consensus Development Panel, Effect of corticosteroids for fetal maturation on perinatal outcomes. NIH Consensus Development Panel on the Effect of Corticosteroids for Fetal Maturation on Perinatal Outcomes. JAMA 1995; 274: 943.6.

16. Ay H, Tosun M, Malatyalıŏlu E, Aygün C, Çetinkaya MB, Handan Çelik $\mathrm{H}$, et al. Comparison of single and double courses of antenatal corticosteroid administration on neonatal mortality and morbidity. J Turkish-German Gynecol Assoc 2010; 11: 38-43.

17. Thorp J, Jones A, Hunt C, Clark R. The effect of multidose antenatal betamethasone on maternal and infant outcomes. Am J Obstet Gynecol 2001; 184: 196-202. [CrossRef] 